\title{
GROWING INTEREST IN ENTREPRENEURSHIP BY UTILIZING LOCAL RESOURCE
}

\author{
Lucky Radi Rinandiyana ${ }^{1}$, Tine Badriatin ${ }^{2}$, Linda Septiana ${ }^{3}$, Elis Listiana Mulyani ${ }^{4}$ \\ 1,2,3,4 Siliwangi University, Tasik, Indonesia \\ ${ }^{1}$ luckyradi@unsil.ac.id, ${ }^{2}$ tinebadriatin@gmail.com, ${ }^{3}$ linda29septiana@gmail.com, \\ ${ }^{4}$ elislistiana@unsil.ac.id
}

\begin{abstract}
Siliwangi University as an educational institution that has one of the responsibilities of community service, Siliwangi University conducts Thematic Work Lecture (KKN) activities in the context of community empowerment through the introduction of the concept of entrepreneurship in several areas of Tasikmalaya Regency, one of them in Dirgahayu Village, Kadipaten District is a village which is located in a mountainous area which has 6 hamlets namely Trowek, Palumbungan, Cijotang, Cipeusing, Cilongkeang and Gekbrong. The focus that we take in Dirgahayu Village is to foster community interest in entrepreneurship, in Dirgahayu village itself there are already a few people who have started entrepreneurship, it's just that the community is still lacking in innovation or utilization of local resources in the village. This is due to the lack of good technology utilization. This service uses counseling method which was attended by 30 people of Dirgahayu Village, especially Youth Organization and PKK ladies. Aiming to provide knowledge and understanding of entrepreneurship by utilizing local resources. The results of this activity are processed cassava products in the form of chips with seblak flavored innovation, however there is still a need to improve product design for product packaging to make it more attractive.
\end{abstract}

Keywords: entrepreneurship, local resources

\section{A. Introduction}

In this modern era, business development can be done in several ways such as counseling through seminars, food processing and product marketing both offline and online. According to Thomas W. Zimmerer and Norman M. Scarbrough "Entrepreneurs are people who create new businesses with take risks and uncertainties to achieve profit and growth by identifying opportunities and combining the resources needed to establish them "(Irham, 2014 :). Based on the desire to provide greater benefits for the community, with all our experience, knowledge, and various survey results and consultations, we conduct counseling about processing cassava plants into various snack products.

Therefore, the 44 KKN UNSIL 2019 group along with participants who provided financial support, hopes that the cassava processing work 
program will become chips as a form of concern for the productivity and creativity of the community in increasing the income and economy of the community. It is hoped that the community, in addition to being able to utilize local resources, will also be able to learn entrepreneurship by trading in marketing the processed home products (Badriatin, T., Agustina, D., \& Rinandiyana, RLR .: 2019).

Besides that, to develop the business talents of the Dirgahayu village community in marketing their products and products in order to be able to make additional value to increase income and increase community insights for entrepreneurship and learn to promote local products in order to compete and be widely marketed (Badriatin, T. , Rinandiyana, LR., \& Mulyani, EL .: 2018).

The availability of local resources and the ability of the community around Dirgahayu Village requires enthusiasm and the ability to communicate from all parties so that the economic prosperity of the village can be felt together (Sudrajat, D. \& Badriatin, T.: 2019)

\section{B. Method of Implementation}

The implementation of this activity uses counseling methods and direct training to PKK cadres of Dirgahayu Village. Dirgahayu PKK cadre was given counseling about the utilization of local resource processing, namely cassava, then the race of products produced from cassava and the calculation of how to produce local materials. According to Mardikanto (2009) counseling is a process of social, economic and political change in empowering and strengthening the ability of the community through participatory shared learning processes, so that behavior changes occur in all the stakeholders (individuals, groups, institutions) involved. The time needed in this counseling is 40 days during the Community Service Program with regular meeting time every Saturday and Sunday with the education and training scheme carried out as follows: 


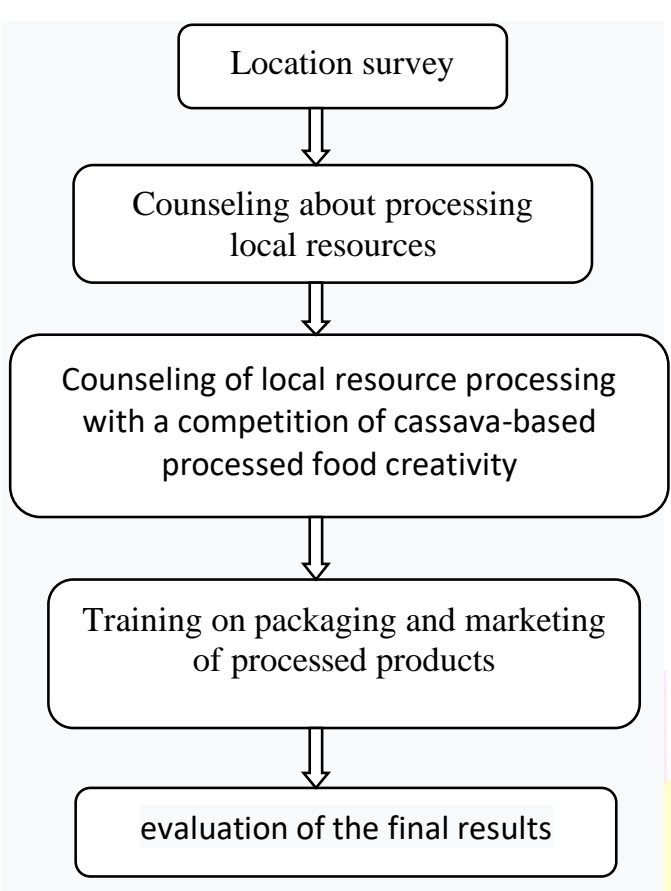

Figure 1. Flow of Community Service Activities

\section{Result and Discussion}

A series of counseling activities such as the Entrepreneurship Seminar held on July 2, 2019 in the Hall of the Dirgahayu Village Hall and delivered by Willy Ramadhan as CEO of Sundanesia, Founder of Dijapri, and BSM Pro Indonesia Tasikmalaya Representative with a discussion on "Dismantling the Secrets of Business Success". Participants who participated as many as 30 people, including people from Dirgahayu Village, especially Youth Organization, Youth / i, Mother PKK,
Head of Village and Village Apparatus.

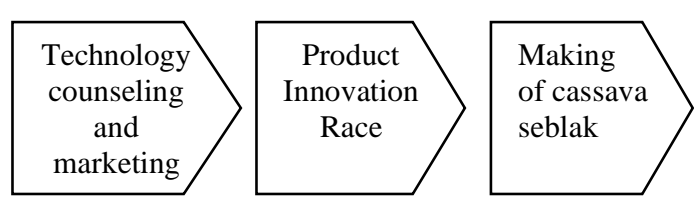

Figure 2. Series of activities

Furthermore, Production Calculation Training is a support program that aims to train the community in calculating input costs so that they can find out the disadvantages and benefits of a business. However, not only to food processing, but we also provide knowledge about packaging techniques, labeling and marketing of digital or online-based products and everything related to entrepreneurship.

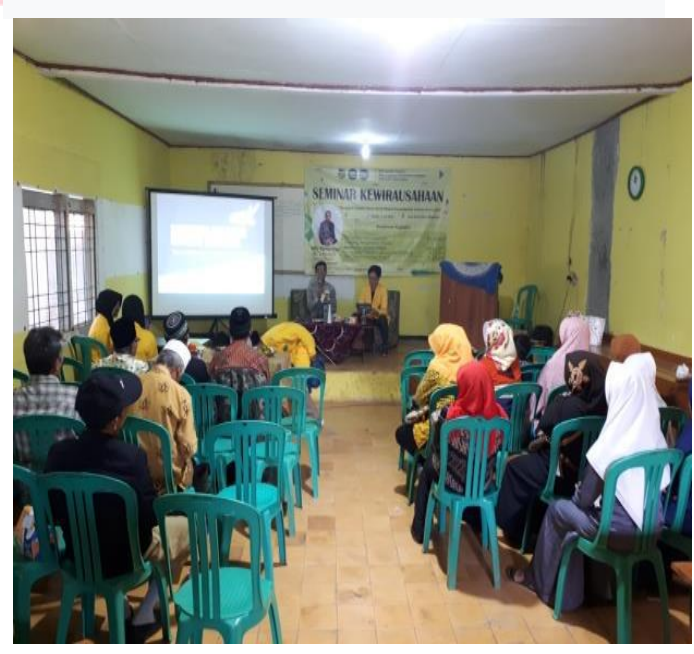

Figure 3. Documentation of Entrepreneurship Seminar Activities 


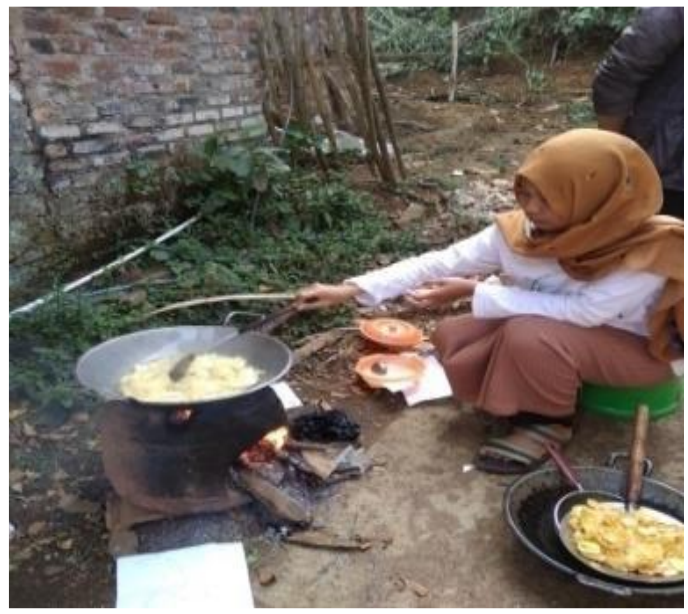

Figure 4. The Process of Making Cassava Flavored Cassava Chips

Projected Profit and Loss / 200kg

Sales Revenue / 200kg:

@ Rp. $8.000 \times 1600$ pcs

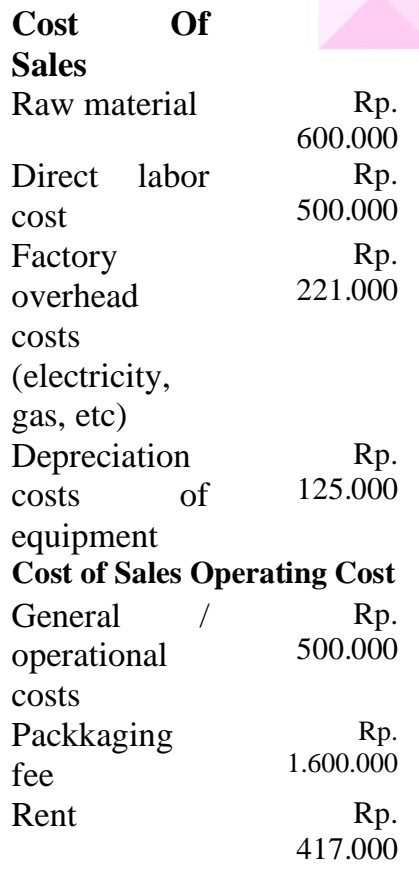

Total Operating Costs Net profit per $200 \mathrm{~kg}$

The equipment has shrunk after use for 1 year $=1 / 12 \mathrm{mth}$ x Rp. 1.500 .000

Rent a place per month for 1 year $=1 / 12 \mathrm{mth} \times \mathrm{Rp}$. 5.000 .000

Figure 4. Projection of Operating Profit

\section{Conclusion}

Based on the activities that have been carried out in community service, it can be concluded that increasing the interest and quality of entrepreneurship that can be an added value for the community's economy in the village of Dirgahayu which focuses on the process of managing food from local resources so that it has a high selling value should be able to increase marketing, packaging and utilization of technology and public facilities available. From some of the problems implemented, it is hoped that the people of Dirgahayu Village can better utilize natural wealth in innovation and creativity for management, packaging and marketing. The process that is expected in the future in the business Rp. 1.446.000 activities of cassava chips with a taste of seblak can continue to run and develop in the village of Dirgahayu so that it can become one of the fostered partners of PT. Pertamina Geothermal Energy (PT. PGE) of the Karaha Area Rp. 125.000 as well as increasing marketing reach Rp.417.000 through Sundanesia and other ecommerce promotion partners and making Dirgahayu Village a better and superior village than before. In this 
activity the results obtained still need

to be developed again where the packaging process in selling seblak flavors of cassava chips still needs to be changed to make it more attractive in better packaging.

\section{REFERENCES}

Badriatin, T., Rinandiyana, LR., \& Mulyani, EL. (2018). Pemasaran Produk UMKM Binaan Pada Pasar Keuangan Rakyat. JMM : Jurnal Masyarakat Mandiri. Vol. 2, No. 2, Desember 2018, 149-153. https://doi.org/10.31764/jmm.v2 i2.1326

Badriatin, T. Agustina, D., \& Rinandiyana, LR. (2019) Pelatihan Kewirausahaan Dengan Membuat Bucket Snack sebagai Alternatif Buah Tanagn bagi santri Miftahul Huda Al husna Kecamatan Bungursari Kota Tasikmalaya. Jurnal Pengabdian Masyarakat Bantenese. Vol. 1. (2). 89-98. https://dx.doi.org/10.30657/ps2p m.vli2.1724

Fahmi Irham.2014.Kewirausahaan Teori, Kasus dan Solusi, Bandung:Alfabeta

Mardikanto, Totok. (2009). Sistem Penyuluhan Pertanian. Universitas Sebelas Maret. Surakarta. 467 Hal.

Sudrajat, D. \& Badriatin, T. (2019). Implementation of Village Business Management Board (BUMDes) Cibalanarik Kecamatan Tanjungjaya Tasikmalaya District. PICS-J : Pasundan International Community Services Journal,
Vol.1, No. 1, Desember 2019. 17. http://dx.doi.org/10.23969/pics.v 1i1.2036. 